Printed in Great Britain

\title{
LUMINESCENCE IN POLYNOIDS
}

\section{MEASUREMENTS OF LIGHT INTENSITY}

\author{
By J. A. C. Nicol \\ The Plymouth Laboratory \\ (Text-figs. I-3)

\section{INTRODUCTION}

Many polynoid worms (family Aphroditidae) are luminescent. In recent papers, physiological and histological aspects of polynoid luminescence have been considered in some detail (Bonhomme, 1942; Nicol, 1953, 1954, 1957 a, b). The light appears in the scales or elytra which cover the dorsal surface of the worm. The photocytes form a single epithelial layer on the lower surface of the elytrum. They are concentrated near the centre of the scale and, when the latter is pigmented, there is a clear area above the photogenic tissue through which the light escapes.

Luminescence in polynoids is under nervous control and is evoked by external stimulation. The elytra usually flash repetitively to a single stimulus, and the responses can be analysed by recording from single elytra. Flash duration ranges from 100 to $200 \mathrm{msec}$. There is much variation in flash intensity: initially, consecutive flashes become progressively brighter, owing to facilitation, but fatigue soon sets in and the flashes become fainter and finally die away.

The light of polynoids is emerald-green in colour. Spectral emission extends from about 450 to $680 \mathrm{~m} \mu$, with a maximum at about $515 \mathrm{~m} \mu$ (Nicol, I957c). The spectral emission curve is shown in Fig. I. This information has been utilized to calculate the intensity of polynoid light, in the manner now to be described.

\section{MATERIAL AND METHODS}

The light of two species was measured, viz. Lagisca extenuata and Acholoë astericola. Elytra were removed from the animals under $\mathrm{MgCl}_{2}$-narcosis, and were subsequently washed in sea water. A single elytrum was mounted in a Perspex chamber over a pair of silver electrodes (see Nicol, 1953). Flashing was induced by stimulating with electric shocks: these were square wave pulses, about $2 \mathrm{msec}$ in duration, and up to $\mathrm{Io} \mathrm{V}$ in intensity.

The light was detected by a photomultiplier (E.M.I. type no. 6685), the spectral sensitivity of which had been determined by the National Physical Laboratory. The photocathode of the photomultiplier is $9 \mathrm{~mm}$ in diameter. Sensitivity is maximal in the violet, and falls off steadily at long wavelengths, 
above $500 \mathrm{~m} \mu$ (Fig. 2, curve A). The elytrum was positioned $2 \mathrm{~cm}$ beneath the photomultiplier, so that its upper surface lay beneath the centre of the photocathode, and was parallel to the face of the latter. The light-emitting region of the elytrum is less than $\mathrm{I} \mathrm{mm}^{2}$ in area, and can be regarded as a point-source.

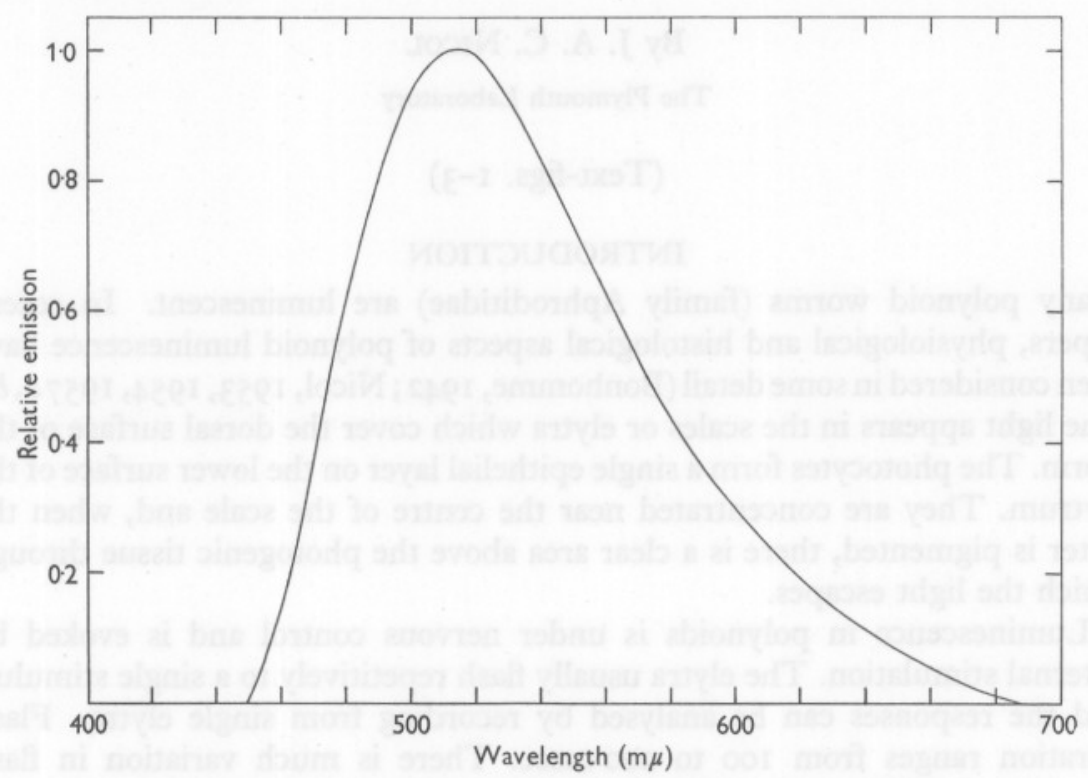

Fig. I. Relative spectral emission curve of polynoid light (from Nicol, 1957c).

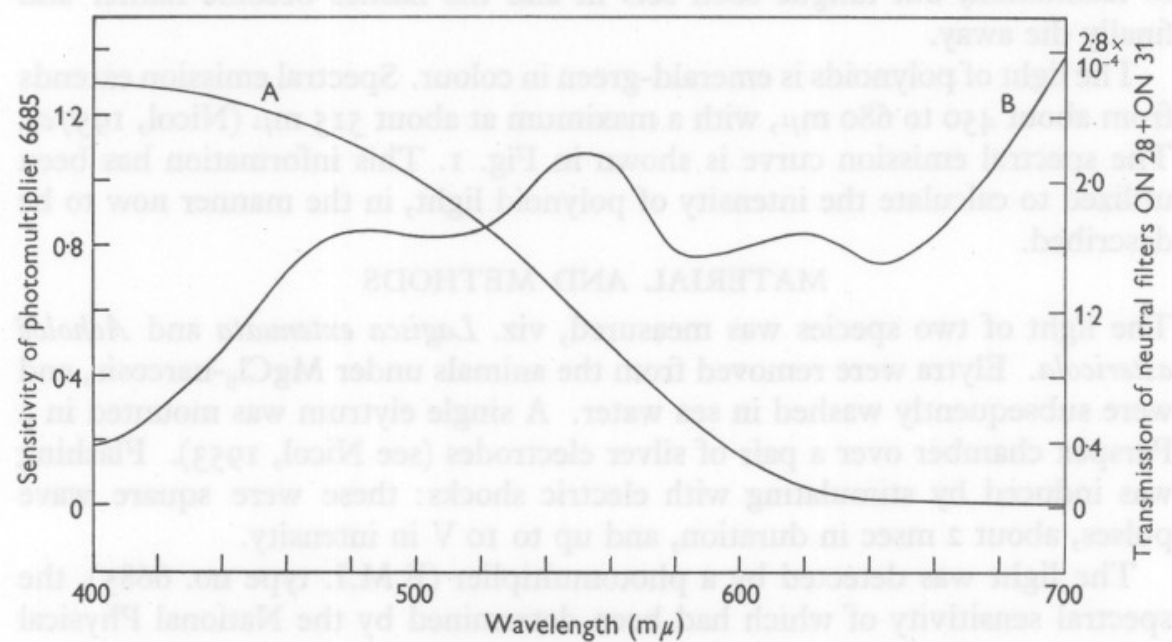

Fig. 2. Curve A: relative spectral sensitivity of photomultiplier type E.M.I. no. 6685 . Curve B: combined transmission of two neutral glass filters (Chance $\mathrm{ON}_{28}+\mathrm{ON}_{3} \mathrm{I}$ ). 
The photomultiplier was connected to a cathode-ray oscilloscope, and photographic records of the responses were made on moving paper.

Measurements were made at ambient temperatures of $18-19^{\circ} \mathrm{C}$.

\section{CALIBRATION OF THE PHOTOMULTIPLIER}

The sensitivity of the apparatus, that is of photomultiplier 6685 plus amplifier and C.R.O., was determined against a known light source. This was a substandard (tungsten) lamp, of colour temperature $2360^{\circ} \mathrm{K}$, and energy output of $24 \cdot 15$ candelas. The lamp was calibrated by the National Physical Laboratory. It was placed on an optical bench $2 \mathrm{~m}$ from the face of the photomultiplier. Intensity was reduced by two neutral glass filters (Chance ON28+ $\mathrm{ON}_{3} \mathrm{I}$ ), the transmission characteristics of which were measured in a spectrophotometer (Unicam SP 500) (see curve B, Fig. 2).

The flux of light from the substandard lamp at $2 \mathrm{~m}$, falling on the surface of the photomultiplier perpendicular to the direction of the light beam, is

$$
\int_{400}^{700} p K \mathscr{F}_{\lambda} V_{\lambda} \mathrm{d} \lambda=p K \int_{400}^{700} \mathcal{F}_{\lambda} V_{\lambda} \mathrm{d} \lambda=I / 4 \times 10^{4} \text { lumens } / \mathrm{cm}^{2} \text {. }
$$

$I$ is the intensity of the substandard lamp in candelas, $p$ is a quantity for the particular experimental set-up, and $K$ is the luminous efficiency of radiation, which is 682 lumens/W at $555 \mathrm{~m} \mu$ (Walsh, 1953):

$$
p=\frac{I}{4 \times 10^{4}} \times \frac{I}{682 \int_{400}^{700} \mathcal{F}_{\lambda} V_{\lambda} \mathrm{d} \lambda} \mathrm{W} / \mathrm{cm}^{2} / \mathrm{m} \mu .
$$

Let the light from the substandard lamp at $2 \mathrm{~m}$, passing through the neutral filters, give a deflexion on the oscilloscope $=D_{L}$. Let $T_{\lambda}$ be the combined transmission of the neutral filters, $S_{\lambda}$ be the spectral sensitivity of the photomultiplier, and $q$ be a constant such that $q / S_{\lambda}=\mathrm{W} / \mathrm{cm}^{2}$ of a given wavelength $(\lambda)$ required to produce unit deflexion. Then

$$
D_{L}=\int_{400}^{700} \frac{p \mathcal{F}_{\lambda} S_{\lambda} T_{\lambda} \mathrm{d} \lambda}{q}=\frac{p}{q} \int_{400}^{700} \mathcal{F}_{\lambda} S_{\lambda} T_{\lambda} \mathrm{d} \lambda
$$

and

$$
q=\frac{p}{D_{L}} \int_{400}^{700} \mathcal{F}_{\lambda} S_{\lambda} T_{\lambda} \mathrm{d} \lambda \mathrm{W} / \mathrm{cm}^{2} .
$$

Values for $V_{\lambda}$ were taken from the C.I.E. table for photopic vision (International Relative Luminous Efficiency of Radiation for Photopic Vision, table VI in Keitz, I955). Values for $\mathscr{F}_{\lambda}$ were obtained from Skogland, I929, for a lamp of colour temperature $2360^{\circ}(\mathcal{F}=\mathrm{I}$ at $\lambda=590 \mathrm{~m} \mu)$.

To determine $p$ and $q$, the following values were used. Intensity, $I$, of the substandard lamp is 24.15 candelas. With set amplification on the C.R.o. 
(30 V/mm), and known voltage on the photomultiplier (I400 V), the deflexion produced by the light is $22.02 \mathrm{~mm}$.

From this quantity, an estimate was made of the deflexion which would be produced at higher amplification, viz. Io $\mathrm{V} / \mathrm{mm}$ on the C.R.o., and photomultiplier voltage of $1600 \mathrm{~V}$. This estimated deflexion was $227.36 \mathrm{~mm}$.

$$
\int_{400}^{700} \mathcal{F}_{\lambda} V_{\lambda}=83 \cdot 52
$$

and

$$
\begin{gathered}
p=\frac{24.15}{4 \times 10^{4}} \times \frac{\mathrm{I}}{682 \times 83.52}=\mathrm{I} \cdot 0599 \times 10^{-8} \mathrm{~W} / \mathrm{cm}^{2} / \mathrm{m} \mu . \\
\int_{400}^{700} \mathcal{F}_{\lambda} S_{\lambda} T_{\lambda} \mathrm{d} \lambda=\mathrm{IO} \cdot \mathrm{I} \times \mathrm{IO}^{-4}
\end{gathered}
$$

and

$$
q=\frac{\mathrm{I} \cdot 0599 \times 10^{-8}}{227.36} \times \mathrm{I0} 5 \cdot \mathrm{I} \times 10^{-4}=0.49 \times \mathrm{IO}^{-12} \mathrm{~W} / \mathrm{cm}^{2} .
$$

In order to make periodical checks on the sensitivity of the apparatus, an alternative light source was employed. This consisted of a stilbene phosphor irradiated by ${ }^{60} \mathrm{Co}$ (called, for brevity, Co source). The phosphor emitted a very faint blue light. Random emission by the phosphor gave a very broad beam-trace, which was smoothed out by putting a $0 \cdot \mathrm{I} \mu \mathrm{F}$ condenser across the input of the oscilloscope. The Co source was set $2 \mathrm{~cm}$ from the face of the photomultiplier, and the oscilloscope deflexion was photographed.

\section{MEASUREMENTS OF THE INTENSITY OF POLYNOID LIGHT}

Records were obtained of the flashes of eight elytra of Lagisca, and of six elytra of Acholoë. Some examples are shown in Fig. 3. Various amplifications were used, and the measured deflexions were calculated on the basis of instrumentsensitivity occurring at a C.R.o. setting of $\mathrm{IO} \mathrm{V} / \mathrm{mm}$ and $\mathrm{I} 600 \mathrm{~V}$ on the phototube. These calculated deflexions, $D_{s}$, for elytra at $2 \mathrm{~cm}$ distance, are shown in columns 2 of Tables I and 2. Column 3 shows calculated deflexions at a distance of $\mathrm{I} \mathrm{m}$, according to the inverse square law.

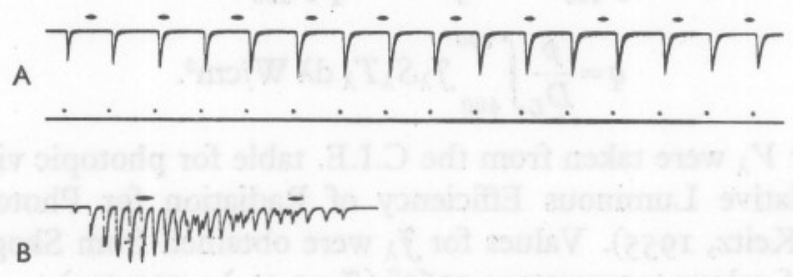

Fig. 3. Oscillograph records of the flashing of polynoid elytra. A, Acholoë, B, Lagisca. Time signal, above, $\mathbf{I} / \mathrm{sec}$. Electrical stimuli on lower line. 
The flashes of polynoids are much briefer than I sec. In order to calculate the energy of one flash, the response curve for a flash was averaged over I sec in terms of a maximal deflexion lasting I sec. These calculations gave factors, A, for response curves of: 0.02 for Lagisca, and 0.084 for Acholoë. The deflexions $\left(D_{s}\right)$ for the responses of Lagisca and Acholoë, averaged over I sec, are shown in columns 4 of Tables I and $2\left(D=D_{s} A\right)$.

TABLE 1. CALCULATION OF THE INTENSITY OF LIGHT EMITTED BY AN ELYTRUM OF LAGISCA

\begin{tabular}{|c|c|c|c|c|c|}
\hline $\begin{array}{l}\text { Elytrum } \\
\text { and record }\end{array}$ & $\begin{array}{c}\text { Maximal } \\
\text { deflexion } \\
D_{s} \text { at } 2 \mathrm{~cm} \\
(\mathrm{~mm})\end{array}$ & $\begin{array}{l}\text { Calculated } \\
\text { deflexion } \\
D_{s} \text { at I m } \\
\text { (mm) }\end{array}$ & $\begin{array}{c}D\left(=A^{\star} \times D_{s}\right) \\
\text { at } \mathrm{I} \mathrm{m}\end{array}$ & $\begin{array}{c}\text { Energy at } \\
5 \mathrm{I} 5 \mathrm{~m} \mu \text { in } \\
\text { I flash, } \mu \mathrm{J} / \mathrm{cm}^{2} \\
\text { at } \mathrm{I} \mathrm{m} \\
\left(\times 10^{-12}\right)\end{array}$ & $\begin{array}{l}\text { Total energy } \\
\text { in I flash, } \\
\mu \mathrm{J} / \mathrm{cm}^{2} \\
\text { at } 1 \mathrm{~m} \\
\left(\times \mathrm{IO}^{-10}\right)\end{array}$ \\
\hline $\begin{array}{r}2 \mathrm{~A} \\
\mathrm{~B} \\
\mathrm{C} \\
\mathrm{D}\end{array}$ & $\begin{array}{l}0.6 \\
0.9 \\
0.3 \\
0.55\end{array}$ & $\begin{array}{l}0.00024 \\
0.00036 \\
0.00012 \\
0.00022\end{array}$ & $\begin{array}{l}0.0000048 \\
0.0000072 \\
0.0000024 \\
0.0000044\end{array}$ & $\begin{array}{l}0.03129 \\
0.046944 \\
0.015648 \\
0.028688\end{array}$ & $\begin{array}{l}0.03309 \\
0.04964 \\
0.01655 \\
0.03034\end{array}$ \\
\hline $\begin{array}{l}3 \mathrm{~A} \\
\mathrm{~B}\end{array}$ & $\begin{array}{r}4 \cdot 1 \\
2 \cdot 5 \\
16 \cdot 5\end{array}$ & $\begin{array}{l}0.00164 \\
0.00100 \\
0.00660\end{array}$ & $\begin{array}{l}0.0000328 \\
0.0000200 \\
0.0001320\end{array}$ & $\begin{array}{l}0.213856 \\
0.13040 \\
0.860640\end{array}$ & $\begin{array}{l}0.226 \text { I }_{5} \\
0.13790 \\
0.91013\end{array}$ \\
\hline $\begin{array}{r}4 \mathrm{~A} \\
\mathrm{~B}\end{array}$ & $\begin{array}{r}0.9 \\
4.5 \\
52.5\end{array}$ & $\begin{array}{l}0.00036 \\
0.00180 \\
0.02100\end{array}$ & $\begin{array}{l}0.0000072 \\
0.0000360 \\
0.0004200\end{array}$ & $\begin{array}{l}0.046944 \\
0.234720 \\
2.73840\end{array}$ & $\begin{array}{l}0.04964 \\
0.24822 \\
2.89586\end{array}$ \\
\hline${ }_{\mathrm{B}}^{5 \mathrm{~A}}$ & $\begin{array}{l}6 \\
3 \cdot 9\end{array}$ & $\begin{array}{l}0.00240 \\
0.00156\end{array}$ & $\begin{array}{l}0.0000480 \\
0.0000312\end{array}$ & $\begin{array}{l}0.31296 \\
0.203424\end{array}$ & $\begin{array}{l}0.33096 \\
0.21512\end{array}$ \\
\hline$\underset{\mathrm{B}}{6 \mathrm{~A}}$ & $\begin{array}{r}3 \\
66\end{array}$ & $\begin{array}{l}0.00120 \\
0.02640\end{array}$ & $\begin{array}{l}0.0000240 \\
0.0005280\end{array}$ & $\begin{array}{l}0.15648 \\
3.44256\end{array}$ & $\begin{array}{l}0.16548 \\
3.64051\end{array}$ \\
\hline${ }_{8}^{7 \mathrm{~B}}$ & $\begin{array}{c}10.8 \\
43.2 \\
6.48\end{array}$ & $\begin{array}{l}0.00432 \\
0.01728 \\
0.002592\end{array}$ & $\begin{array}{l}0.0000864 \\
0.0003456 \\
0.0000518\end{array}$ & $\begin{array}{l}0.56332 \\
2.253312 \\
0.337997\end{array}$ & $\begin{array}{l}0.59572 \\
2.38286 \\
0.35743\end{array}$ \\
\hline${ }_{\mathrm{B}}^{9 \mathrm{~A}}$ & $\begin{array}{l}8 \cdot 64 \\
1 \cdot 44\end{array}$ & $\begin{array}{l}0.003456 \\
0.000576\end{array}$ & $\begin{array}{l}0.0000691 \\
0.0000115\end{array}$ & $\begin{array}{l}0.450662 \\
0.075110\end{array}$ & $\begin{array}{l}0.47658 \\
0.07943\end{array}$ \\
\hline
\end{tabular}

TABLE 2. CALCULATION OF THE INTENSITY OF LIGHT EMITTED BY AN ELYTRUM OF $A C H O L O \ddot{E}$

\begin{tabular}{|c|c|c|c|c|c|}
\hline $\begin{array}{l}\text { Elytrum } \\
\text { and } \\
\text { record }\end{array}$ & $\begin{array}{l}\text { Maximal } \\
\text { deflexion } \\
D_{s} \text { at } 2 \mathrm{~cm} \\
(\mathrm{~mm})\end{array}$ & $\begin{array}{c}\text { Calculated } \\
\text { deflexion } \\
D_{s} \text { at } \mathrm{Im} \\
\left(\times \mathrm{IO}^{-4}\right) \\
(\mathrm{mm})\end{array}$ & $\begin{array}{c}D\left(=A^{\star} \times D_{s}\right. \\
\text { at } \mathrm{I} \mathrm{m}) \\
\left(\times \mathrm{IO}^{-4}\right)\end{array}$ & $\begin{array}{c}\text { Energy at } \\
515 \mathrm{~m} \mu \text { in } \\
\text { I flash, } \mu \mathrm{J} / \mathrm{cm}^{2} \\
\text { at } \mathrm{Im} \\
\left(\times 10^{-10}\right)\end{array}$ & $\begin{array}{l}\text { Total energy } \\
\text { in I flash, } \\
\mu \mathrm{J} / \mathrm{cm}^{2} \\
\text { at } \mathrm{Im} \\
\left(\times \mathrm{IO}^{-8}\right)\end{array}$ \\
\hline${ }_{\mathrm{B}}^{\mathrm{A}}$ & $\begin{array}{l}r \cdot 824 \\
8.683\end{array}$ & $\begin{array}{r}7 \cdot 296 \\
34 \cdot 732\end{array}$ & $\begin{array}{l}0.6129 \\
2.9175\end{array}$ & $\begin{array}{l}0.39961 \\
I \cdot 9022 I\end{array}$ & $\begin{array}{l}0.42259 \\
2.01159\end{array}$ \\
\hline 2 & 0.917 & 3.668 & $0.308 \mathrm{I}$ & 0.20089 & 0.21244 \\
\hline${ }^{5 \mathrm{~A}}$ & $\begin{array}{l}1 \cdot 643 \\
7 \cdot 126\end{array}$ & $\begin{array}{r}6.572 \\
28.504\end{array}$ & $\begin{array}{l}0.5520 \\
2 \cdot 3943\end{array}$ & $\begin{array}{l}0.35994 \\
\text { I.56I08 }\end{array}$ & $\begin{array}{l}0.38064 \\
I \cdot 65084\end{array}$ \\
\hline 8 & I. 376 & 5.504 & 0.4624 & 0.30148 & 0.31882 \\
\hline${ }_{\mathrm{B}}^{9 \mathrm{~A}}$ & $\begin{array}{l}\mathrm{r} \cdot 099 \\
\mathrm{I} \cdot 985\end{array}$ & $\begin{array}{l}4.396 \\
7.940\end{array}$ & $\begin{array}{l}0.3693 \\
0.6670\end{array}$ & $\begin{array}{l}0.24078 \\
0.43488\end{array}$ & $\begin{array}{l}0.25462 \\
0.45989\end{array}$ \\
\hline
\end{tabular}


A relative spectral emission curve for polynoid light is shown in Fig. I, in which relative energy, $E_{\lambda}$, is plotted against $\lambda(\mathrm{Nicol}, \mathrm{I} 957 \mathrm{c})$. This curve can be put on an absolute basis in terms of a quantity $r$ such that $E_{\lambda} r$ gives Watts $/ \mathrm{cm}^{2}$ of receptor surface $/ \mathrm{m} \mu$ under the experimental conditions specified.

$$
\begin{gathered}
D=\int \frac{r E_{\lambda} S_{\lambda}}{q} \mathrm{~d} \lambda, \quad D=\frac{r}{q} \int E_{\lambda} S_{\lambda} \mathrm{d} \lambda . \\
r=\frac{D q}{\int E_{\lambda} S_{\lambda} \mathrm{d} \lambda} \mathrm{W} / \mathrm{cm}^{2} / \mathrm{m} \mu, \quad \int_{400}^{700} E_{\lambda} S_{\lambda} \mathrm{d} \lambda=75 \cdot \mathrm{I}, \\
r=D \times \frac{0.49 \times \mathrm{IO}^{-12}}{75 \cdot \mathrm{I}}=D \times 0.652 \times \mathrm{IO}^{-14} \mathrm{~W} / \mathrm{cm}^{2} / \mathrm{m} \mu .
\end{gathered}
$$

The energy at $515 \mathrm{~m} \mu$ in I flash is equal to

$$
r=D \times 0.652 \times 10^{-14} \mathrm{~W} / \mathrm{cm}^{2} / \mathrm{m} \mu \text { at } \mathrm{I} \mathrm{m} .
$$

The total energy in I flash is equal to

$$
r \int_{400}^{700} E_{\lambda} \mathrm{d} \lambda=D \times 0.652 \times \mathrm{IO}^{-14} \int_{400}^{700} E_{\lambda} \mathrm{d} \lambda \mathrm{W} / \mathrm{cm}^{2} \text { at } \mathrm{I} \mathrm{m} .
$$

From integration of the curve in Fig. I,

$$
E_{\lambda} \mathrm{d} \lambda=\mathrm{I05} \cdot 75 \text {. }
$$

Values for energy in I flash at $5 \mathrm{I} 5 \mathrm{~m} \mu$, and for total energy in I flash, are shown in columns 5 and 6 of Tables I and 2. For Lagisca the total energy in a flash ranges from $0.017 \times 10^{-10}$ to $3.64 \mathrm{I} \times 10^{-10} \mu \mathrm{J} / \mathrm{cm}^{2}$ at $\mathrm{I} \mathrm{m}$. For Acholoë, the total energy in a flash ranges from $0.2 \mathrm{I} 2 \times 10^{-8}$ to $2.012 \times \mathrm{IO}^{-8} \mu \mathrm{J} /$ $\mathrm{cm}^{2}$ at $\mathrm{I} \mathrm{m}$.

These values were determined by measuring that light which was emitted in a cone having its axis perpendicular to the upper surface of the elytrum, and possessing a solid angle $w=0 \cdot 16$ sterad.

The data and calculations of Tables I and 2 pertain to a single flash. Polynoid elytra usually flash repetitively, so that there may be I or many flashes in a given second; at fast rates there is often some degree of summation. A calculation for Lagisca gives the following results:

(a) Total energy in a single brief flash (maximal flash in a series of flashes): $0 . \mathrm{I} 82 \times 1 \mathrm{IO}^{-9} \mu \mathrm{J} / \mathrm{cm}^{2}$ at $\mathrm{I} \mathrm{m}$.

(b) Total flux in a series of $\mathrm{I}_{3}$ flashes occurring in I sec (maximal flash intensity as in $(a)): 2.600 \times 10^{-9} \mu \mathrm{W} / \mathrm{cm}^{2}$ at $\mathrm{I} \mathrm{m}$. 


\section{INTENSITY OF LIGHT EMITTED PER PHOTOCYTE}

The photocytes lie in a single cellular layer. This arrangement permits an estimation of the light emitted per photocyte. Elytra were sectioned (at $7 \mu$ ), and the total number of photocytes counted. In elytrum no. 7 of Lagisca there were 1250 photocytes. Minimal and maximal values for the light emitted by a photocyte in I flash are: minimum, $0.048 \times 10^{-12} \mu \mathrm{J} / \mathrm{cm}^{2}$ at I $\mathrm{m}$; maximum, $0.19 \mathrm{I} \times 10^{-12} \mu \mathrm{J} / \mathrm{cm}^{2}$ at $\mathrm{I} \mathrm{m}$.

\section{COMMENT}

Mean values for the intensity of light emitted in a single flash by an elytrum of Lagisca are I. $8 \times \mathrm{IO}^{-6} \mu \mathrm{J} / \mathrm{cm}^{2}$ at I cm, and I $8 \times \mathrm{IO}^{-10} \mu \mathrm{J} / \mathrm{cm}^{2}$ at I m. Corresponding values for the flash of an elytrum of Acholoë are I.II $\times I^{-4} \mu \mathrm{J} / \mathrm{cm}^{2}$ at I $\mathrm{cm}$ and I.II $\times \mathrm{IO}^{-8} \mu \mathrm{J} / \mathrm{cm}^{2}$ at I m. These estimates are for air-paths.

Some estimations are available for the radiant flux emitted by other marine species. The luminescence of a ctenophore Mnemiopsis leidyi, $35 \mathrm{~mm}$ in diameter, was $0.5 \times 10^{-4}$ to $>0.75 \times 10^{-4} \mu \mathrm{W} / \mathrm{cm}^{2}$ at $50 \mathrm{~cm}$ (recalculated as $0.125 \times 10^{-4}$ to $>0.187 \times 10^{-4} \mu \mathrm{W} / \mathrm{cm}^{2}$ at I $\mathrm{m}$ in air) (Clarke $\&$ Backus, I956). The light of Euphausia pacifica has a mean intensity of $\mathrm{I} \cdot 8 \times \mathrm{IO}^{-3} \mu \mathrm{W} / \mathrm{cm}^{2}$ at I cm. An adult Euphausia pacifica is about $20 \mathrm{~mm}$ long and has Io lightemitting organs (photophores). The light intensity of Pyrosoma atlantica ranges from $8 \times 10^{-3}$ to $4 \times 10^{-2} \mu \mathrm{W} / \mathrm{cm}^{2}$ at $\mathrm{I} \mathrm{cm}$. A colony $10 \mathrm{~cm}$ long emitted light of intensity $2.5 \times 10^{-2} \mu \mathrm{W} / \mathrm{cm}^{2}$ at I $\mathrm{cm}$ (Kampa \& Boden, 1957).

The flashes of polynoids are shorter than I sec. If the light of these worms remained constant during I sec at maximal flash intensity, then the radiant flux for an elytrum of Lagisca and Acholoë, respectively, would be: $0.9 \times 10^{-4}$ and $\mathrm{I} \cdot 3 \mathrm{I} \times \mathrm{IO}^{-3} \mu \mathrm{W} / \mathrm{cm}^{2}$ at $\mathrm{I} \mathrm{cm}$ (in air). These values for radiant flux of polynoid elytra are of about the same order as that for Euphausia. Ctenophores and Pyrosomas are much bigger animals, with correspondingly larger light-emitting surfaces.

The light emitted in I flash by a single photocyte of Lagisca is $0.12 \times 10^{-12}$ $\mu \mathrm{J} / \mathrm{cm}^{2}$ receptor surface at I m. For a flash of $\mathrm{I}$ sec duration, the estimated radiant flux would be $\mathrm{I} \cdot 3 \times \mathrm{IO}^{-12} \mu \mathrm{W} / \mathrm{cm}^{2}$ receptor surface at $\mathrm{I} \mathrm{m}$. Harvey (1925) has estimated the total radiant flux emitted by a single bacterium of Bacillus phosphorescens to be $4.95 \times 10^{-10} \mu \mathrm{W}$ at $\lambda=510 \mathrm{~m} \mu$ (the wavelength of maximal emission). Over the entire emission spectrum (i.e. $\int_{400}^{700} E_{\lambda} \mathrm{d} \lambda$ ), the radiant flux emitted by a single bacterium is about $0.4 \times 10^{-12} \mu \mathrm{W} / \mathrm{cm}^{2}$ receptor surface at $\mathrm{I} \mathrm{m}$. I have recently estimated the energy in a single brief flash from a cell of Noctiluca miliaris to be about $\mathrm{I} \cdot \mathrm{I} \times \mathrm{IO}^{-12} \mu \mathrm{J} / \mathrm{cm}^{2}$ receptor surface at $\mathrm{I} \mathrm{m}$ (in air) (unpublished research). This is about ten times greater than the light output of a photocyte of Lagisca. 
The threshold of the dark-adapted human eye for a flash having a duration $<0 . \mathrm{I} \mathrm{sec}$ is about Ioo quanta at $510 \mathrm{~m} \mu$ in a test field of Io' (Graham \& Margaria, 1935; Hecht, Shlaer, \& Pirenne, 1942; Pirenne \& Denton, 1952). When fully exposed, the human pupil has an area, mean $S=0.5 \mathrm{~cm}^{2}$. Now, I quantum at $510 \mathrm{~m} \mu=4 \times 10^{-12} \mathrm{erg}$. For a just detectable flash, the human eye needs 100 quanta $=4 \times 10^{-10} \mathrm{erg}$ to fall in the pupil, area $S$.

The mean value for energy in a flash of Lagisca is $\mathrm{I} \cdot 8 \times 10^{-10} \mu \mathrm{J} / \mathrm{cm}^{2}$ receptor surface at $\mathrm{I} \mathrm{m}$, or $\mathrm{I} \cdot 8 \times \mathrm{IO}^{-9} \mathrm{erg} / \mathrm{cm}^{2}$ receptor surface at $\mathrm{I} \mathrm{m}$.

At $x \mathrm{~m}$, the equivalent energy, if all were concentrated at $5 \mathrm{IO} \mathrm{m} \mu$, in a polynoid flash

$$
\begin{aligned}
& =\frac{\mathrm{I} \cdot \mathrm{I} \times \mathrm{IO}^{-9}}{x^{2}} \mathrm{erg} / \mathrm{cm}^{2} \text { receptor surface } \\
& =\frac{\mathrm{I} \cdot \mathrm{I} \times \mathrm{I} \mathrm{O}^{-9}}{x^{2}} S \mathrm{erg} / \text { mean pupil area. }
\end{aligned}
$$

The distance in air at which an average flash of Lagisca can be seen, by the dark-adapted human eye, is given by

$$
\begin{aligned}
4 \times \mathrm{IO}^{-10} \mathrm{erg} & =\frac{\mathrm{I} \cdot \mathrm{I} \times \mathrm{IO}^{-9}}{x^{2}} S \mathrm{erg} / \text { mean pupil area, } \\
x^{2} & =\frac{\mathrm{I} \cdot \mathrm{I} \times \mathrm{IO}^{-9} \times 0 \cdot 5}{4 \times \mathrm{IO}^{-10}} \text { metres squared, } \\
x & =\mathrm{I} \cdot 2 \mathrm{~m} .
\end{aligned}
$$

I am indebted to Dr E. J. Denton for guidance in the calculations of light intensity. Part of the apparatus was purchased with grants from the Royal Society. The ${ }^{60} \mathrm{Co}$-stilbene light source was devised and loaned by Dr G. N. Harding of the U.K. Atomic Energy Authority, to whom I am grateful.

\section{SUMMARY}

The light energy emitted in a flash by single elytra of two polynoid worms has been measured, viz. Acholoë astericola and Lagisca extenuata. Maximal emission occurs at $5 \mathrm{I} 5 \mathrm{~m} \mu$. Mean values for light intensity per flash from I elytrum are: Lagisca, I.8 $\times \mathrm{IO}^{-10} \mu \mathrm{J} / \mathrm{cm}^{2}$ receptor surface at I m; Acholoë, $\mathrm{I} \cdot \mathrm{II} \times \mathrm{IO}^{-8} \mu \mathrm{J} / \mathrm{cm}^{2}$ receptor surface at $\mathrm{I} \mathrm{m}$. The light emitted in I flash by a single photocyte of Lagisca is $0.12 \times 10^{-12} \mu \mathrm{J} / \mathrm{cm}^{2}$ receptor surface at $\mathrm{I} \mathrm{m}$. It is estimated that the light from I elytrum of Lagisca could be seen by the dark-adapted human eye at $\mathrm{I} \cdot 2 \mathrm{~m}$ in air. 


\section{REFERENCES}

Bonнomme, C., I942. Recherches sur l'histologie de l'appareil lumineux des Polynoïnés. Bull. Inst. océanogr. Monaco, Vol. 39, No. 823, 8 pp.

ClaARK, G. L. \& BACKUS, R. H., 1956. Measurements of light penetration in relation to vertical migration and records of luminescence of deep-sea animals. Deep-Sea Res., Vol. 4, pp. I-I4.

Graham, C. H. \& Margaria, R., I935. Area and the intensity-time relation in the peripheral retina. Amer. F. Physiol., Vol. I13, pp. 299-305.

HARVEY, E. N., I925. The total luminous efficiency of luminous bacteria. F.gen. Physiol., Vol. 8, pp. 89-108.

Hecht, S., Shlaer, S. \& Pirenne, M. H., 1942. Energy, quanta and vision. F. gen. Physiol., Vol. 25, pp. 819-40.

KAMPA, E. M. \& BoDEN, B. P., I957. Light generation in a sonic-scattering layer. Deep-Sea Res., Vol. 4, pp. 73-92.

KeITz, H. A. E., 1955. Light Calculations and Measurements. Eindhoven: Philips's Technical Library.

Nicol, J. A. C., 1953. Luminescence in polynoid worms. F. mar. biol. Ass. U.K., Vol. 32, pp. 65-84.

— 1954. The nervous control of luminescent responses in polynoid worms. F. mar. biol. Ass. U.K., Vol. 33, pp. 225-55.

- 1957a. Luminescence in polynoids. II. Different modes of response in the elytra. F. mar. biol. Ass. U.K., Vol. 36, pp. 26I-9.

- $1957 b$. Luminescence in polynoids. III. Propagation of excitation through the nerve cord. F. mar. biol. Ass. U.K., Vol. 36, pp. $271-3$.

- 1957c. Spectral composition of the light of polynoid worms. F. mar. biol. Ass. U.K., Vol. 36, pp. 529-38.

Pirenne, M. H. \& Denton, E. J., 1952. Accuracy and sensitivity of the human eye. Nature, Lond., Vol. 170, pp. 1039-42.

SKogland, J. F., 1929. Tables of spectral energy distribution and luminosity for use in computing light transmissions and relative brightnesses from spectrophotometric data. Misc. Publ. U.S. Dept. Commerce, No. 86, 23 pp.

Walsh, J. W. T., 1953. Photometry. London: Constable. 